University of Nebraska - Lincoln

DigitalCommons@University of Nebraska - Lincoln

\title{
Geochemical and mineralogical evidence from eolian sediments for northwesterly mid-Holocene paleowinds, central Kansas, USA
}

\author{
Alan F. Arbogast \\ Michigan State University \\ Daniel R. Muhs \\ U.S. Geological Survey, dmuhs@usgs.gov
}

Follow this and additional works at: https://digitalcommons.unl.edu/usgsstaffpub

Part of the Earth Sciences Commons

Arbogast, Alan F. and Muhs, Daniel R., "Geochemical and mineralogical evidence from eolian sediments for northwesterly mid-Holocene paleowinds, central Kansas, USA" (2000). USGS Staff -- Published Research. 170.

https://digitalcommons.unl.edu/usgsstaffpub/170

This Article is brought to you for free and open access by the US Geological Survey at DigitalCommons@University of Nebraska - Lincoln. It has been accepted for inclusion in USGS Staff -- Published Research by an authorized administrator of DigitalCommons@University of Nebraska - Lincoln. 


\title{
Geochemical and mineralogical evidence from eolian sediments for northwesterly mid-Holocene paleowinds, central Kansas, USA
}

\author{
Alan F. Arbogast ${ }^{\mathrm{a}, *}$, Daniel R. Muhs ${ }^{\mathrm{b}}$ \\ ${ }^{a}$ Department of Geography, 315 Natural Science, Michigan State University, East Lansing, MI 48824-1115 USA \\ ${ }^{\mathrm{b}}$ U.S. Geological Survey, MS 980, Box 25046, Federal Center, Denver, CO 80225 USA
}

Received 15 January 2000; accepted 10 February 2000

\begin{abstract}
A prominent $\left(4500 \mathrm{~km}^{2}\right)$ dune field in the Great Plains is the Great Bend Sand Prairie of south-central Kansas. Dunes here overlie late Quaternary alluvium and were reactivated extensively in the late Holocene. Geomorphic and soil evidence suggests that the most likely eolian sand source is the Arkansas River valley to the northwest. Nevertheless, orientations of stabilized dunes indicate that the most recent dune-forming winds came from the south or southwest, in agreement with modern wind data.

Mineralogy and trace element concentrations in eolian sands of the Great Bend Sand Prairie are similar to those of the Arkansas River, which permits the Arkansas River as a sediment source. Ca and $\mathrm{Sr}$ abundances, which reflect small amounts of carbonate minerals, are higher in Arkansas River sand compared to eolian sands and show a systematic depletion away from the Arkansas River to the southeast. These trends are likely due to carbonate mineral depletion downwind from abrasion and size reduction. Thus, paleowinds probably were northwesterly during initial deposition. Northwesterly winds occur today when dry, Pacific-derived air is dominant. We hypothesize that the residence time of this air mass was much greater while dunes initially formed, possibly during a warmer and drier mid-Holocene period. (C) 2000 Elsevier Science Ltd and INQUA. All rights reserved.
\end{abstract}

\section{Introduction}

Deposits of eolian sand are common in the semiarid to subhumid central and southern Great Plains (Fig. 1), with large dune fields and sand sheets present in Nebraska (Ahlbrandt et al., 1983; Swinehart, 1990; Loope et al., 1995), northeastern Colorado (Madole, 1995; Muhs et al., 1996), Texas (Holliday, 1995a), and Kansas (Arbogast, 1996a, b). One of the largest dune fields $\left(\sim 4500 \mathrm{~km}^{2}\right)$ of the Great Plains is the Great Bend Sand Prairie in Kansas, located within the "great bend" of the Arkansas River in the south-central part of the state (Fig. 2). Arbogast (1996a) reported that dunes within the region formed largely in the late Holocene, with significant reactivation in the past millennium. Dunes are presently stable because the climate is sufficiently mesic to support a grassland vegetation.

Although eolian sands occur almost continuously along the south side of the Arkansas River in Kansas and eastern Colorado, orientations of late Holocene dunes differ from west to east (Figs. 1 and 3). Although winds are strong over the entire region, modern wind data

* Corresponding author. (discussed in more detail below) indicate that net sand movement should be to the north in south-central Kansas and to the southeast in westernmost Kansas and eastern Colorado (Fig. 3). In Colorado and western Kansas, stabilized parabolic dunes, estimated to be of Holocene age on the basis of soil development, have orientations indicating northwesterly paleowinds. East of Garden City, however, stabilized parabolic dunes all have southerly or southwesterly orientations, in agreement with the dominant modern winds (Fig. 3). These observations indicate that the latest Holocene eolian activity has been a function of winds that differ little from those of today.

Despite the evidence for southerly winds as a control on the movement of dune sand in south-central Kansas, few sources of sand exist to the south of the dune belt. Late Quaternary loess occurs immediately south of much of the region (Ross et al., 1991). Farther east, to the southeast of the Great Bend Sand Prairie, early or middle Pleistocene alluvial sands and gravels are found (Ross et al., 1991). Although this alluvium could be a potential source of eolian sand, most deposits have very welldeveloped soils with $\mathrm{Bt}$, Btk, or Bk horizons, indicating little if any removal of material by wind during the late Quaternary. The degree of soil development effectively

1040-6182/00/\$20.00 (C) 2000 Elsevier Science Ltd and INQUA. All rights reserved. 


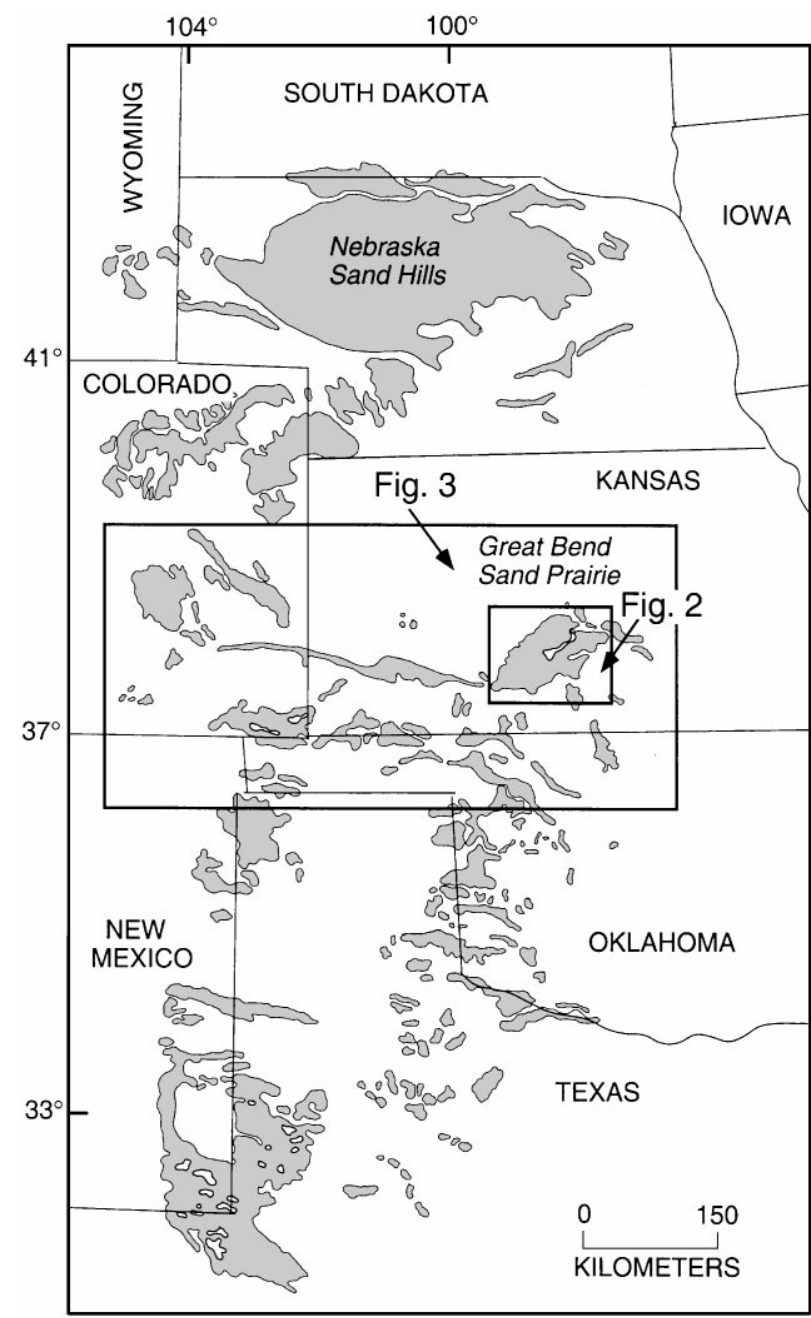

Fig. 1. Map showing the distribution of eolian sand in the central and southern Great Plains and the location of the Great Bend Sand Prairie. Distribution of eolian sand from Muhs and Holliday (1995).

eliminates this older alluvium as a potential source for eolian sand on the Great Bend Sand Prairie. Stratigraphic and radiocarbon evidence presented by Arbogast (1996a) also indicates that the oldest eolian sands are no older than early Holocene and, at most localities, are mid-to-late Holocene.

The contradictory observations of dune-building from southerly winds and lack of a sand source has generated discussion of the origin of central and western Kansas eolian sand for more than 50 years. Smith (1940, p. 166) pointed out the lack of evidence for modern eolian movement of sand out of the Arkansas River valley and seemed to reject this as a source for eolian sand. Later, however, Smith (1940, p. 168) seemed to accept an Arkansas River valley origin by appealing to northerly winds that occurred during the late Wisconsin period. Stramel et al. (1958) suggested that erosion of sands that underlie late Quaternary loess, which in turn underlies the dune sands, may have been the source of sand, implying a southerly paleowind. Simonett (1960), however, rejected this hypothesis on the basis of deep drilling data; he pointed out that in most areas, the underlying late Wisconsin loess was too thick and covered too much of the underlying sands and gravels for this latter sediment to have been a significant source. Instead, Simonett (1960) accepted Smith's (1940) later hypothesis that the dunes formed from an Arkansas River valley source under late Wisconsin paleowinds that were from the north. However, the late Wisconsin age for the time of dune-building proposed by Smith (1940) and Simonett (1960) cannot be reconciled with the Holocene stratigraphic and radiocarbon evidence presented by Arbogast (1996a) and Arbogast and Johnson (1998) for the Great Bend Sand Prairie.

In this study, we reconsider the origin of eolian sands in the Great Bend Sand Prairie. We hypothesize that the Arkansas River was the source of eolian sands, but initial dune building took place under paleowinds different from those of the present. In order to test this hypothesis, it is necessary to: (1) confirm that the Arkansas River could be a source, (2) find evidence of winds from the north or northwest, and (3) find independent paleoclimatic evidence that conditions were favorable for active eolian sand migration at the time winds were from the north or northwest. Mineralogy and trace element abundances are used to determine if the Arkansas River is a potential source, and other element concentrations are used to infer paleowinds and assess the mineralogical maturity of the dune field. Holocene paleoclimatic evidence is assessed from published pollen and fluvial records, as well as eolian sand records from nearby areas.

\section{Methods}

Eolian sand samples were collected over most of the Great Bend Sand Prairie, well below the zone of pedogenesis to eliminate any mineral alteration by weathering. Eolian sands were collected from dunes and sheet sands that had both minimally developed soils with A/AC/C profiles (Tivoli series, a Typic Ustipsamment) and better-developed soils with $\mathrm{A} / \mathrm{Bt} / \mathrm{C}$ profiles (Pratt series, a Psammentic Haplustalf). Samples of modern Arkansas River alluvium were also collected from bar and bank exposures along the entire reach of the river that borders the Great Bend Sand Prairie to the west and northwest. Modern alluvium contains particles that range from clay to gravel. Therefore, after destruction of organic matter with $\mathrm{H}_{2} \mathrm{O}_{2}$ and dispersion with Na-pyrophosphate, these samples were sieved to remove silt and clay $(<53 \mu \mathrm{m})$ and coarse sand and gravel ( $>425 \mu \mathrm{m})$. The retained sediments have a particle size distribution that is similar to that found in eolian sands in the area (Arbogast and Johnson, 1998). Alluvial samples were not leached with $\mathrm{HCl}$ prior to dispersion and sieving, however, because we wished to determine concentrations of 


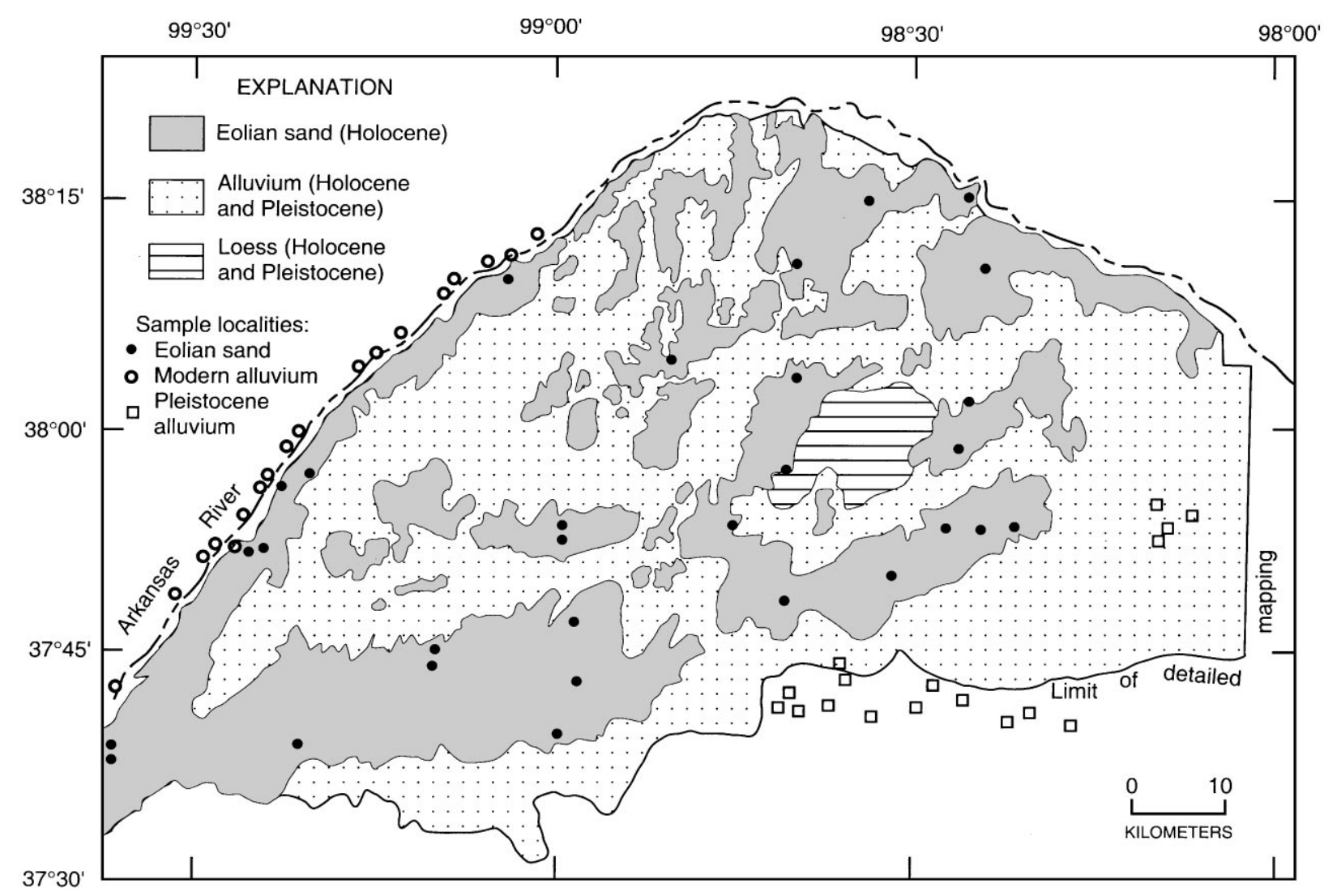

Fig. 2. Surficial geology of the Great Bend Sand Prairie area and sample localities. Geology from Arbogast (1996a, 1998) and Arbogast and Johnson (1998). Note that six additional Arkansas River samples were collected between the western border of the map and just west of Dodge City, Kansas (see Fig. 3).

elements that could be indicative of carbonate minerals. Although it is possible that some flocculation of clays could have been maintained by not removing carbonates, this is considered unlikely given the very small quantities of silt and clay contained in the alluvial samples. Semiquantitative mineral abundances were determined by X-ray diffraction for quartz $\left(20.8^{\circ} 2 \theta\right)$, K-feldspar $\left(24.7^{\circ} 2 \theta\right)$, plagioclase $\left(27.9^{\circ} 2 \theta\right)$, calcite $\left(29.4^{\circ} 2 \theta\right)$, and dolomite $\left(30.8^{\circ} 2 \theta\right)$, using peak heights. Concentrations of K, $\mathrm{Ca}, \mathrm{Ti}, \mathrm{Rb}, \mathrm{Sr}, \mathrm{Y}, \mathrm{Nb}, \mathrm{Zr}, \mathrm{Ba}, \mathrm{La}$, and $\mathrm{Ce}$ were determined by energy-dispersive $\mathrm{X}$-ray fluorescence, following the approach used by Muhs et al. (1995, 1996, 1997a, b). Concentrations of $\mathrm{La}$ and $\mathrm{Nb}$ were below detection levels in many samples and therefore were not used in interpretations.

\section{Sand-moving winds in central and western Kansas}

The Great Bend Sand Prairie lies near the junction of two very different wind regimes. An understanding of how these winds vary seasonally is crucial to paleoclimate studies within the region. Sand-moving winds are best described graphically by means of sand roses, which are circular histograms of winds above the threshold velocity for sand transport (Fryberger and Dean, 1979).
The arms in a sand rose are weighted sums of the amount of time that the wind is above the threshold velocity for sand from a given direction; weights are applied to higher-velocity winds because the sand-moving ability of wind is a function of the cube of wind speed. Fryberger and Dean (1979) define several parameters from sand rose data: drift potential (DP), which is the scalar sum of all sand-moving winds, regardless of direction; resultant drift potential (RDP), which is the vector sum of all sand-moving winds; and resultant drift direction (RDD), which is the net direction of sand movement. Good agreement between RDD values and dune orientations from many parts of the world suggest that it is a valuable parameter in studying dune forms and their relation to winds (Fryberger and Dean, 1979; Breed et al., 1979; Ahlbrandt and Fryberger, 1980; Lancaster et al., 1987; Lancaster, 1988; Wells et al., 1990; Muhs et al., 1995, 1996, 1997a, b). Six stations along the Arkansas River in central and western Kansas and eastern Colorado have sufficient data for the construction of sand roses. For simplicity, we show RDP values only, as single arrows.

Wind regimes differ dramatically from eastern Colorado to central Kansas (Fig. 3). At Pueblo, La Junta and Garden City, RDDs are from the northwest because northwesterly winds are dominant at these localities for 


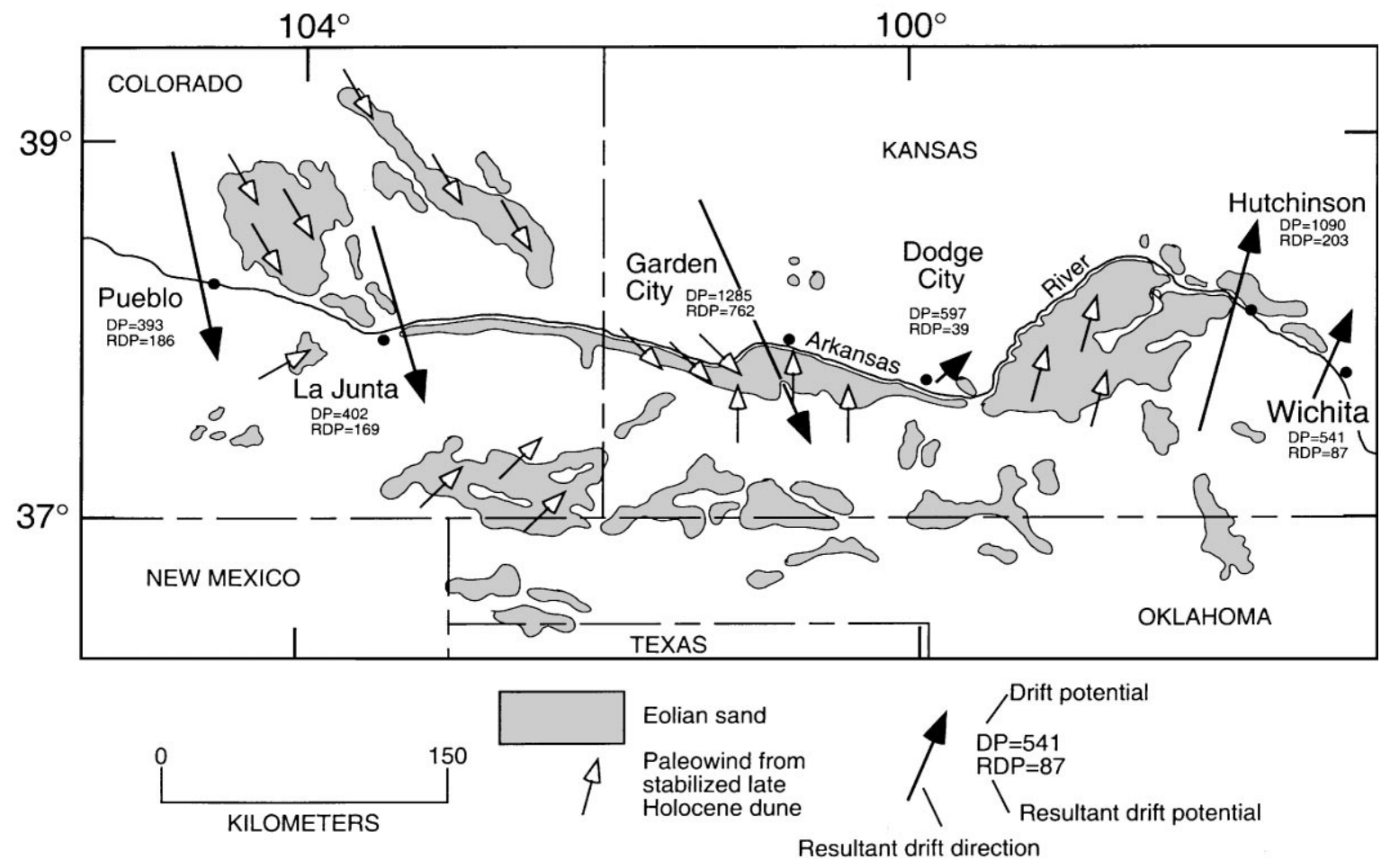

Fig. 3. Drift potential (DP), resultant drift potential (RDP), and resultant drift directions (RDD) for six localities in eastern Colorado and western Kansas, and paleowinds derived from orientations of stabilized sand dunes. Wind parameters calculated by the authors from data provided by the National Climatic Data Center. Paleowinds in eastern Colorado from Madole (1995), for the Great Bend Sand Prairie from Arbogast and Johnson (1998), and for western Kansas from the present study.

at least six months per year (La Junta and Garden City) and up to 10 months per year (Pueblo). RDP values are relatively high and range from 169 vector units (La Junta) to 762 vector units (Garden City). Between Garden City and Dodge City, the overall wind regime shifts from northwesterly to southwesterly. DP is relatively high at Dodge City (597), but RDP is low (39), the result of nearly equal opposing northerly and southerly winds. Northwesterly winds are dominant for five months (November-March) at Dodge City, but southerly or southwesterly winds are dominant the other seven months. Farther east, at Hutchinson, on the eastern boundary of the Great Bend Sand Prairie, southerly winds are very strong for seven months of the year (April-October) and both DP and RDP (with southwesterly winds) are high (1090 and 203, respectively). For the most part, orientations of stabilized late Holocene dunes match the resultant drift potentials, but dune orientations become highly variable between Dodge City and Garden City, where the shift in wind regime is located.

The shift from northwesterly winds, dominant in the west, to southwesterly winds farther east is a function of the differing residence times of major air masses. Bryson (1966) showed that three air masses share dominance over the North American midcontinent: (1) moderate, dry Pacific air, (2) cold, dry Arctic air, and (3) warm, moist Gulf of Mexico air. Eastern Colorado and westcentral Kansas are affected mostly by dry Pacific air (with northwesterly winds) during the winter months and moist, tropical air from the Gulf of Mexico (with southerly winds) during the late spring, summer, and early fall. The residence time of dry Pacific air decreases from west to east, and is therefore greatest at Pueblo and lowest at Wichita. Precipitation regimes reflect this difference in residence time as well, being lowest at Pueblo and La Junta ( $\sim 280 \mathrm{~mm} / \mathrm{yr}$ ) and highest at Hutchinson and Wichita $(\sim 745 \mathrm{~mm} / \mathrm{yr})$, where there is a greater residence time of moist, Gulf of Mexico-derived air.

\section{Mineralogy and geochemistry of eolian sand and Arkansas River sand}

Mineralogical analyses show that the compositions of Great Bend eolian sands and Arkansas River sands are similar (Fig. 4). Although Great Bend eolian sands are dominated by quartz, they have relatively high abundances of both K-feldspar and plagioclase compared to many dune fields (McKee, 1983; Dutta et al., 1993). In addition to their silicate mineral similarities, both Arkansas River sands and Great Bend eolian sands contain small (perhaps $1-5 \%$ ) but detectable amounts of calcite and dolomite. 

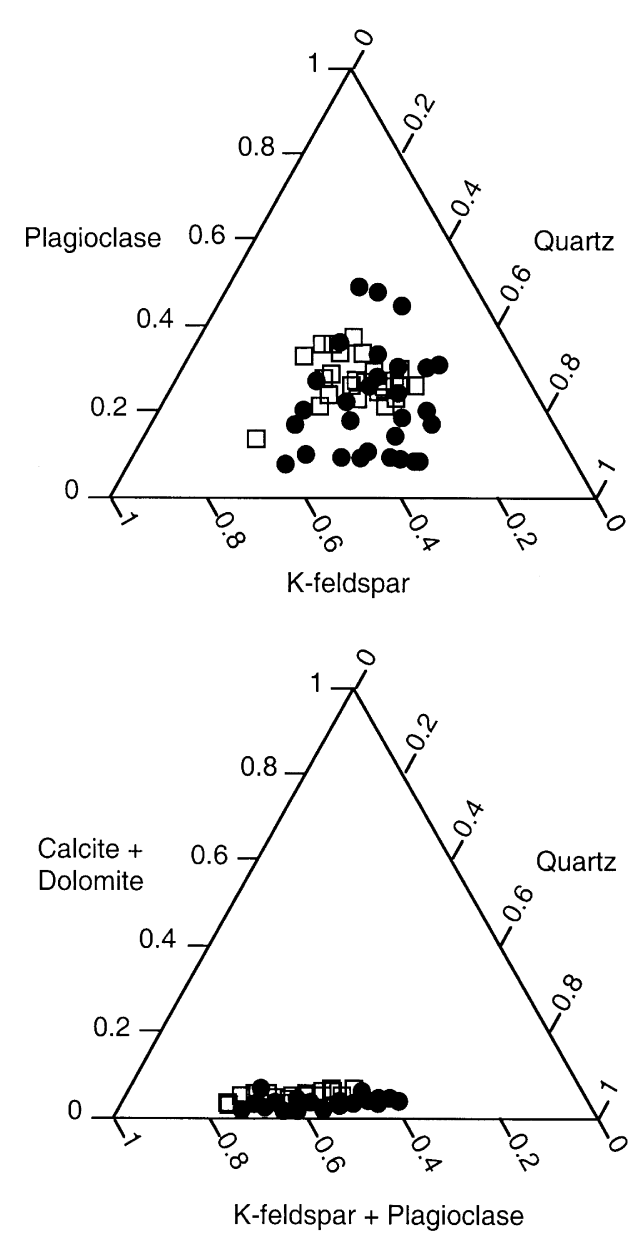

- Great Bend eolian sand

$\square$ Arkansas River sand

Fig. 4. Ternary plots showing relative abundances of quartz, K-feldspar, plagioclase, calcite and dolomite in Great Bend Sand Prairie and Arkansas River sands.

The major and trace elements studied are indicators of the mineralogy of eolian and alluvial sands. $\mathrm{K}, \mathrm{Rb}$, and $\mathrm{Ba}$ are found dominantly in K-bearing minerals, particularly K-feldspar and micas. Micas, because of their platy morphology, are not common in eolian sand. Thus, $\mathrm{K}$-feldspar is the most likely carrier of $\mathrm{K}, \mathrm{Rb}$, and $\mathrm{Ba}$ in eolian sand, but both $\mathrm{K}$-feldspar and micas may be the carriers of $\mathrm{K}, \mathrm{Rb}$, and $\mathrm{Ba}$ in alluvial sand. $\mathrm{Ca}$ and $\mathrm{Sr}$ are found in Ca-bearing minerals, which include calcic plagioclase but also carbonate minerals such as calcite and dolomite. $\mathrm{La}$ and $\mathrm{Ce}$ are light rare earths, and $\mathrm{Y}$ has chemical behavior similar to the heavy rare earths. The rare earth elements are found in a wide variety of minerals, and are particularly abundant in monazite, apatite and biotite. However, most of the $\mathrm{Y}$ and rare earth abundances in these samples are probably accounted for by feldspars. $\mathrm{Zr}$ is present almost exclusively in zircon. Ti is found mainly in ilmenite, anatase, rutile, titanomagnetite, and sphene.

In assessing sources for eolian sand, certain elements are more useful than others. $\mathrm{K}, \mathrm{Rb}$, and $\mathrm{Ba}$ occur in $\mathrm{K}$-feldspar, which is subject to physical breakdown in eolian settings due to ballistic impacts (Dutta et al., 1993). Muhs et al. (1997a) suggested that the K-feldspar-depleted Nebraska Sand Hills may owe its mineralogical maturity in part to this process, probably through repeated activation over a long interval of time. Pye and Tsoar (1990, p. 82) noted that soft carbonate minerals such as calcite and dolomite ought to be more easily abraded to finer particle sizes and therefore ultimately depleted in dune fields. Experimental studies by Marsland and Woodruff (1937) and Kuenen (1960) demonstrated that calcite particles are indeed reduced in size by eolian abrasion in laboratory experiments. A recent field study in North Dakota also suggests that this process is important and occurs relatively quickly. Muhs et al. (1997b) showed that dune sands in the Minot dune field in North Dakota, derived from highly calcareous glaciofluvial and glaciolacustrine deposits, have experienced almost complete calcite and dolomite removal in less than 10,000 years.

Chemically immobile elements were chosen for comparison of Great Bend Sand Prairie eolian sands and the sand fraction of Arkansas River sediments (Fig. 5). A plot of Ti vs. Zr shows rough linearity for Arkansas River sand, which reflects the presence of both elements in heavy minerals. These values overlap those of the eolian sands, although mean $\mathrm{Ti} / \mathrm{Zr}$ values differ between the two sediment groups. A plot of $\mathrm{Ce}$ vs. $\mathrm{Y}$ shows far less linearity than for $\mathrm{Ti}$ and $\mathrm{Zr}$ and probably reflects the diversity of minerals (high concentrations in rare monazite and apatite, but low concentrations in abundant feldspars) in which these two elements are found. Nevertheless, Arkansas River sands and Great Bend eolian sands show significant overlap in both $\mathrm{Ce}$ and $\mathrm{Y}$ concentrations. We conclude that it would probably be useful to acquire additional geochemical and perhaps isotopic data (e.g., Aleinikoff et al., 1999) in order to confirm the Arkansas River as a source of sand for the Great Bend Sand Prairie. Nevertheless, on the basis of mineralogy and, to a lesser extent, the $\mathrm{Ti}-\mathrm{Zr}-\mathrm{Ce}-\mathrm{Y}$ data, it appears that Arkansas River sand is the likely source of eolian sand in this region.

A more definitive identification of the Arkansas River as an eolian sediment source can be obtained from mineral depletion trends. As discussed above, dune sand that originally contained carbonates should show depletions of these minerals over time (Pye and Tsoar, 1990). It follows from this hypothesis that before all carbonate minerals are removed (as in the case of the Minot dune field discussed above), there should be a systematic depletion of carbonate minerals away from a source, because farther-traveled particles 

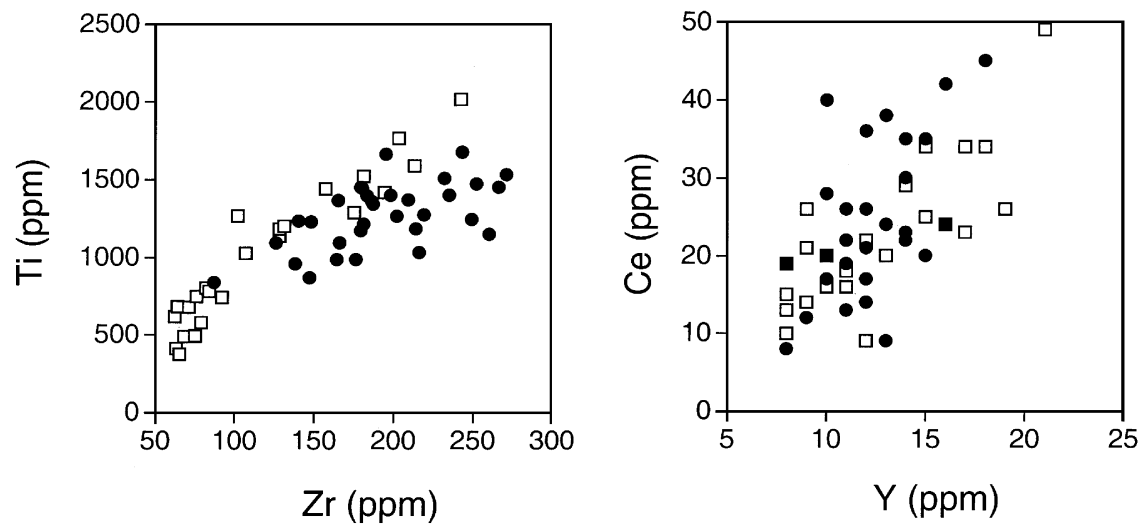

- Great Bend eolian sand

Arkansas River sand

Fig. 5. Plots of Ti vs. Zr and Ce vs. Y for eolian sands from the Great Bend Sand Prairie and sands from the Arkansas River.

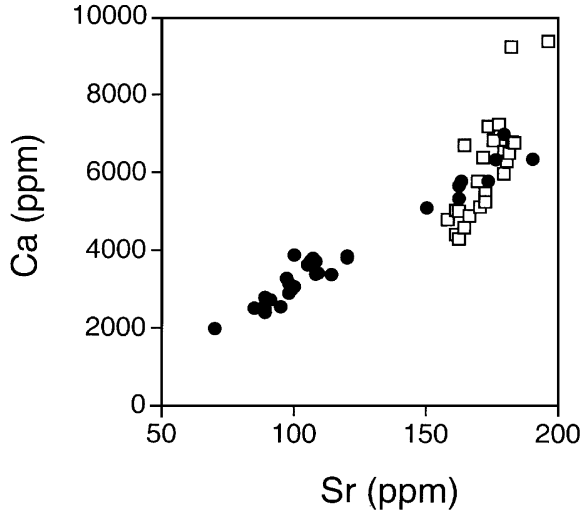

- $\quad$ Great Bend eolian sand

․ Arkansas River sand

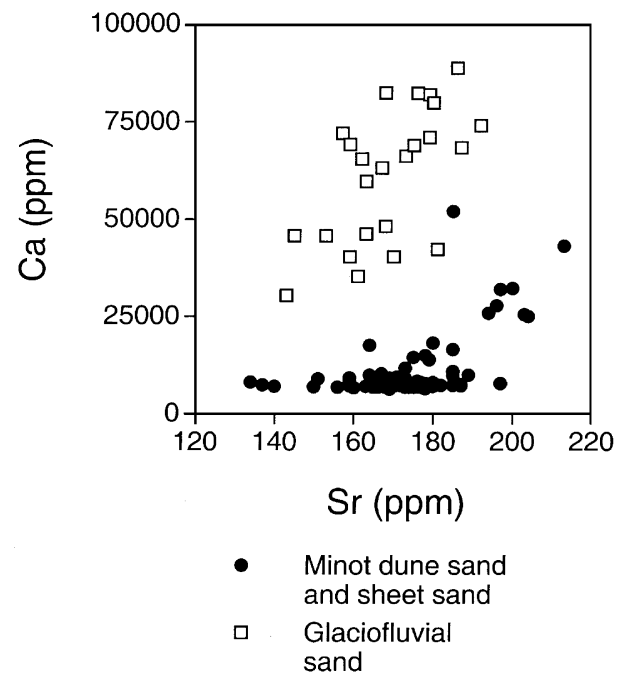

Fig. 6. Plots of Ca vs. Sr for eolian sands from the Great Bend Sand Prairie and sands from the Arkansas River. Shown for comparison are similar data (from Muhs et al., 1997b) from the Minot dune field in North Dakota.

should have experienced more abrasion and size reduction.

Carbonate mineral abundances in eolian sand from the Great Bend Sand Prairie, as reflected in $\mathrm{Ca}$ and $\mathrm{Sr}$ concentrations, are significantly lower than in Arkansas River sand. Arkansas River sand contains low but detectable amounts of carbonate minerals (Fig. 4), and mean $\mathrm{Ca}$ and $\mathrm{Sr}$ concentrations are $\sim 6100$ and $170 \mathrm{ppm}$, respectively $(n=24)$. In the Great Bend Sand Prairie, eolian sands have lower mean values for these elements $(\mathrm{Ca}=3800$ ppm; $\mathrm{Sr}=116 \mathrm{ppm} ; n=32)$, with the highest values found immediately to the east or southeast of the river valley (Figs. 6 and 7). Shown also for comparison in Fig. 6 is a similar plot of $\mathrm{Ca}$ and $\mathrm{Sr}$ concentrations in the Minot dune field of North Dakota and its source sediment. The source of the eolian sand in North Dakota is calcite- and dolomite-rich glaciofluvial sediment, which is reflected in the higher Ca concentrations compared to sands of the Arkansas River. Muhs et al. (1997b) attributed the lower $\mathrm{Ca}$ concentrations in Minot dune sand to eolian abrasion, reduction to silt sizes, and eolian removal from the dune field via suspension. The relatively high $\mathrm{Sr}$ concentrations in the Minot dune sands reflect the presence of non-carbonate, Ca-bearing minerals.

The spatial distribution of $\mathrm{Ca}$ and $\mathrm{Sr}$ abundances in the Great Bend Sand Prairie support the hypothesis that the Arkansas River is the most likely source for eolian sand in the region. Contours of $\mathrm{Ca}$ and $\mathrm{Sr}$ abundances in eolian sand of the Great Bend Sand Prairie indicate a general northwest-to-southeast decrease away from the Arkansas River (Figs. 7 and 8). These trends suggest greater depletion of carbonate minerals away from an 


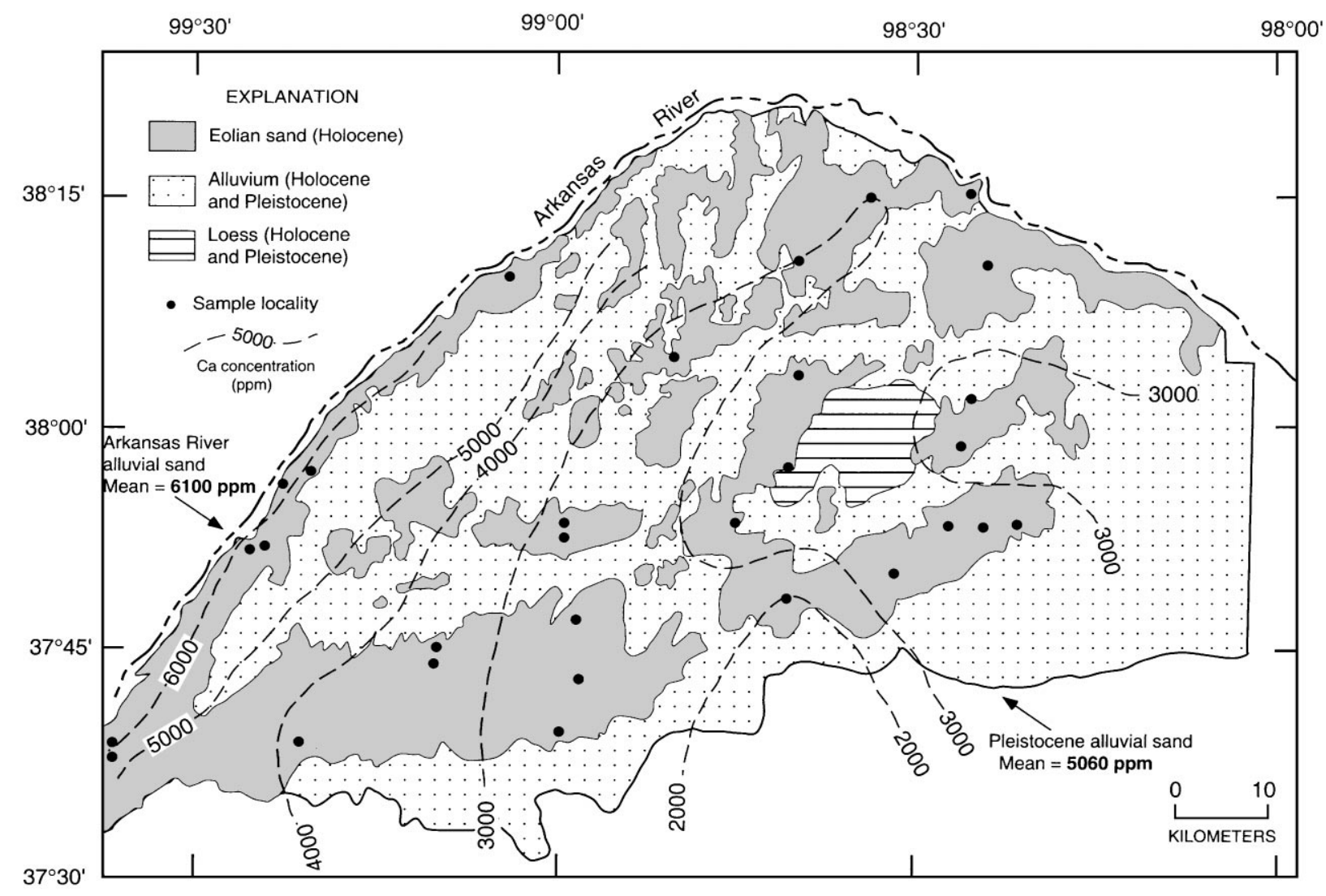

Fig. 7. Map showing general northwest-to-southeast decrease in Ca content in the Great Bend Sand Prairie. Geology from Arbogast (1996a, 1998) and Arbogast and Johnson (1998).

Arkansas River valley source, due to eolian abrasion over a greater distance of transport.

An alternative explanation for the $\mathrm{Ca}$ and $\mathrm{Sr}$ trends is that eolian sand was derived from nearby Pleistocene alluvium, which, hypothetically, could be lower in $\mathrm{Ca}$ and $\mathrm{Sr}$ than modern Arkansas River sand. Such a potential source is the Pleistocene alluvium that directly underlies the eolian sands on the Great Bend Sand Prairie. This unit is not a likely source for eolian sands, however, because these deposits contain extremely well developed soils with thick ( $>1 \mathrm{~m}$ ) Bt and Btk horizons (Arbogast and Johnson, 1998). Thus, these deposits could not have provided the volume of sand contained within the overlying dunes in Holocene time.

Another potential Pleistocene source for eolian sand is the alluvium that occurs to the south and east of the dune field (Fig. 2; Ross et al., 1991). As discussed earlier, this older alluvium is also an unlikely eolian sand source based on the degree of soil development found in its upper part. Nonetheless, the broad expanse of these deposits, coupled with the prevailing (modern) southerly winds suggests that this older alluvium is a more likely source than the alluvium that underlies the dune field, and, if depleted in $\mathrm{Ca}$ and $\mathrm{Sr}$, could possibly explain the northwest-to-southeast $\mathrm{Ca}$ and $\mathrm{Sr}$ trends in the Great
Bend Sand Prairie. Thus, samples were collected from unaltered parts of this alluvium southeast of the dune field (Fig. 2). These samples show $\mathrm{Ca}$ and $\mathrm{Sr}$ concentrations that are much higher than in nearby eolian sands (Figs. 7 and 8). We conclude from these data that $\mathrm{Ca}$ - and Sr-depleted Pleistocene alluvium does not explain the spatial trends observed in the Great Bend Sand Praire eolian sand.

On the basis of soil-geomorphic relations (lack of an eroded sediment source beneath or to the south of the dune field), mineralogical data, $\mathrm{Ca}-\mathrm{Sr}$ contours, and, to a lesser extent, $\mathrm{Ti}-\mathrm{Zr}-\mathrm{Ce}-\mathrm{Y}$ data, we conclude that the Arkansas River was probably the main source for eolian sand in the Great Bend Sand Prairie. Identification of an Arkansas River source implies paleowinds from the northwest. Northwesterly paleowinds differ from modern resultant drift directions, and indicate that at some time in the Holocene, paleoclimatic conditions differed from those of the present.

\section{Mineralogical maturity of the Great Bend Sand Prairie}

Certain geochemical data allow assessment of the mineralogical maturity of dune fields. Mineralogical 


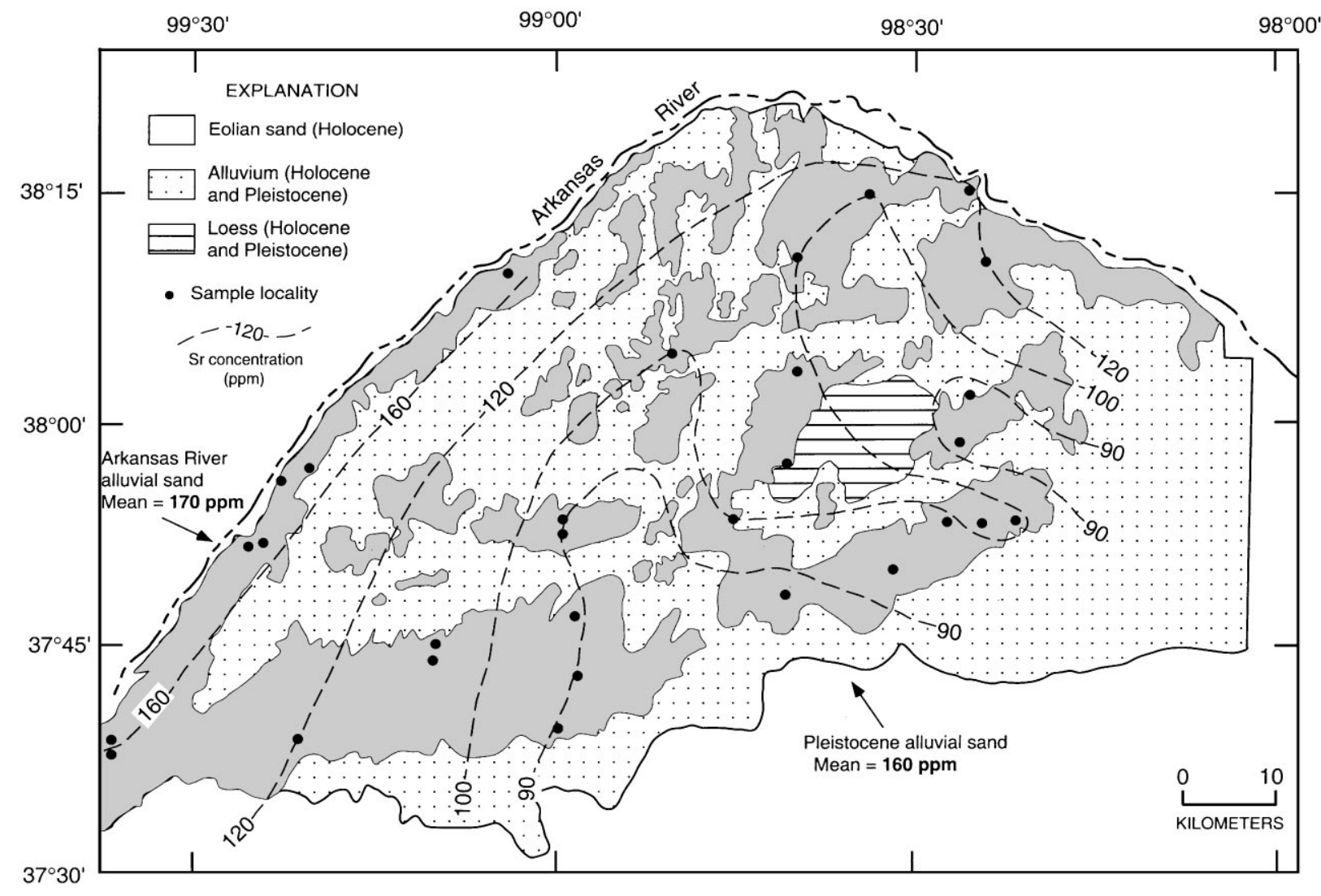

Fig. 8. Map showing general northwest-to-southeast decrease in Sr content in the Great Bend Sand Prairie. Geology from Arbogast (1996a, 1998) and Arbogast and Johnson (1998).

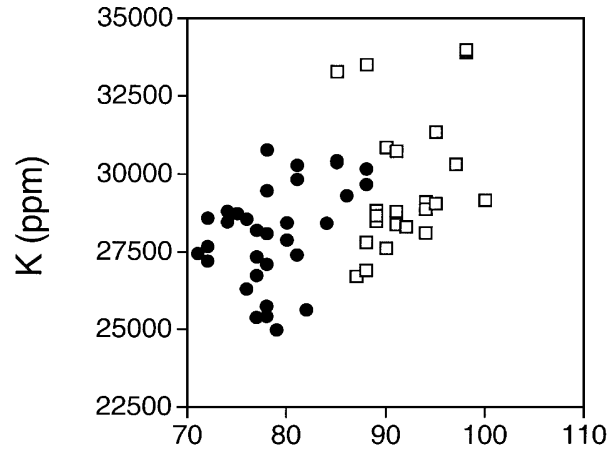

$\mathrm{Rb}(\mathrm{ppm})$

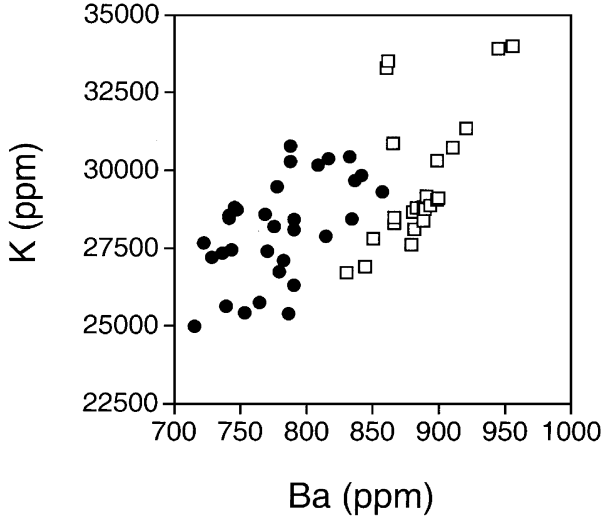

- Great Bend eolian sand

口 Arkansas River alluvial sand

Fig. 9. Plots of K vs. $\mathrm{Rb}$ and $\mathrm{K}$ vs. Ba for eolian sands from the Great Bend Sand Prairie and sands from the Arkansas River.

maturity in sandstones or sandy sediments derived from crystalline rocks is characterized by an abundance of quartz and depletion of feldspars (Blatt et al., 1972). Viewed in this way, many of the world's largest sand seas are mineralogically mature (Cooke and Warren, 1973; McKee, 1983; Pye and Tsoar, 1990). Mineralogical ma- turity in a dune field can simply be inherited from a feldspar-poor source sediment (e.g., Muhs et al., 1995) or may be the result of processes acting over a long period of time on a feldspar-rich source sediment. In the latter case, feldspar depletion could take place by weathering and pedogenic processes during long periods of dune 
stability. Because K-feldspar is fairly resistant to chemical weathering, however, it is more likely that $\mathrm{K}$-feldspar depletion takes place by ballistic impacts during extended periods of dune activity (Dutta et al., 1993). $\mathrm{K}$-feldspar depletion, if not inherited from the source sediment, is indicative of a dune field with a long history of activity. Recent studies suggest that, on the basis of K, $\mathrm{Rb}$, and $\mathrm{Ba}$ abundances, dune fields in northeastern Colorado are relatively immature mineralogically whereas the Nebraska Sand Hills are mineralogically mature, compared to their respective source sediments (Muhs et al., 1996; 1997a).

Based on stratigraphic relations and Holocene radiocarbon ages reported by Arbogast (1996a) and Arbogast and Johnson (1998), we would expect the dunes of the Great Bend Sand Prairie to be relatively immature mineralogically. Plots of $\mathrm{K}$ vs. $\mathrm{Rb}$ and $\mathrm{K}$ vs. Ba show possible evidence of partial depletion of $\mathrm{K}$-feldspar in eolian sands compared to Arkansas River sands (Fig. 9). Values of $\mathrm{Rb}$ and $\mathrm{Ba}$ are, on average, lower in eolian sands compared to alluvial sands, although concentrations of $\mathrm{K}$ are only slightly lower in eolian sands compared to alluvial sands (note that a $t$-test showed lower concentrations of $\mathrm{K}$ in eolian sands, significant at the 99.5\% level). However, the higher $\mathrm{K}, \mathrm{Rb}$, and Ba concentrations in Arkansas River sands may be explained by the presence of mica, which, as noted earlier, is not normally abundant in eolian sands. Furthermore, the amount of $\mathrm{K}$-feldspar depletion, if any has occurred, is too small to be detectable by X-ray diffraction methods (Fig. 4). Comparison of mineralogical data (Fig. 10) and $\mathrm{K}-\mathrm{Rb}-\mathrm{Ba}$ abundances in eolian sands (Fig. 11) shows that the composition of the Great Bend Sand Prairie more closely resembles that of dune fields of northeastern Colorado than the Nebraska Sand Hills. We conclude from these comparisons that if Arkansas River sands are the source of eolian sands in the Great Bend Sand Prairie, it is a relatively youthful dune field, consistent with Holocene radiocarbon ages reported by Arbogast (1996a) and Arbogast and Johnson (1998).

\section{Paleoclimatic implications of northwesterly paleowinds}

If the Arkansas River was the source of sand for the Great Bend Sand Prairie, it would be desirable to have independent paleoclimatic evidence of a Holocene period with a greater residence time of dry, Pacific-derived air than at present. Such evidence could be pollen, fluvial, or other eolian records showing a dry period, because drier conditions result from Pacific-derived air over the region. Unfortunately, there are few Holocene pollen records for Kansas. The best-dated and most detailed study is from Cheyenne Bottoms, a locality $\sim 10 \mathrm{~km}$ north of the "great bend" of the Arkansas River (Fredlund, 1995). Fredlund's data show a depression in Cheno-Am percentages and a rise in Ambrosia percentages during the
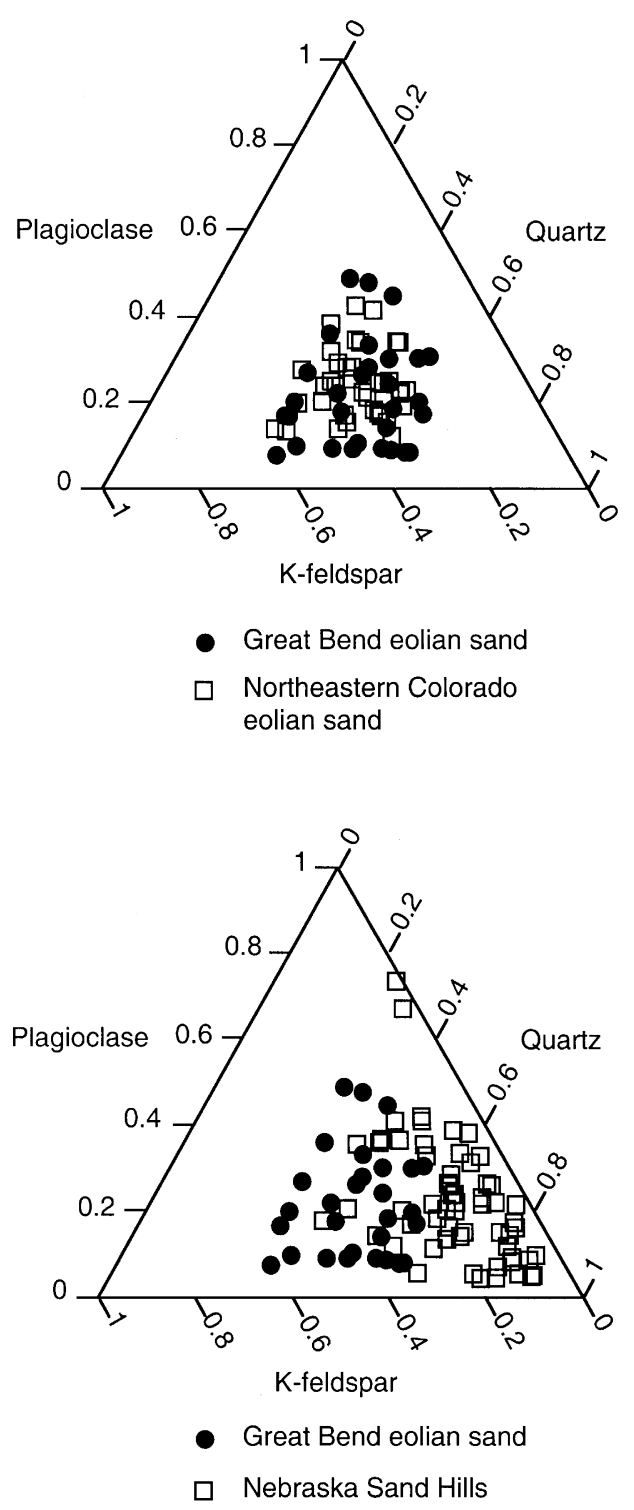

Fig. 10. Ternary plots showing relative abundances of quartz, Kfeldspar and plagioclase in eolian sands from the Great Bend Sand Prairie, northeastern Colorado, and the Nebraska Sand Hills. Nebraska data from Muhs et al. (1997a); Colorado data from Muhs et al. (1996).

period from $\sim 8500$ to $3700 \mathrm{yr} \mathrm{BP}$, which he interprets to be weak but discernible evidence for a mid-Holocene dry period. Areas to the north and south of central Kansas also indicate a mid-Holocene dry period. Pollen evidence from Iowa indicates replacement of early Holocene mesic deciduous forest by prairie due to drier conditions from 6300 to $3500 \mathrm{yr} \mathrm{BP}$, only to be later replaced by mixed forest and prairie (Baker et al., 1998). A regional synthesis of pollen data over much of the upper Midwest of Minnesota and Wisconsin indicates generally drier conditions in the interval from $\sim 9000$ to $6000 \mathrm{yr} \mathrm{BP}$ (Webb et al., 1993). 


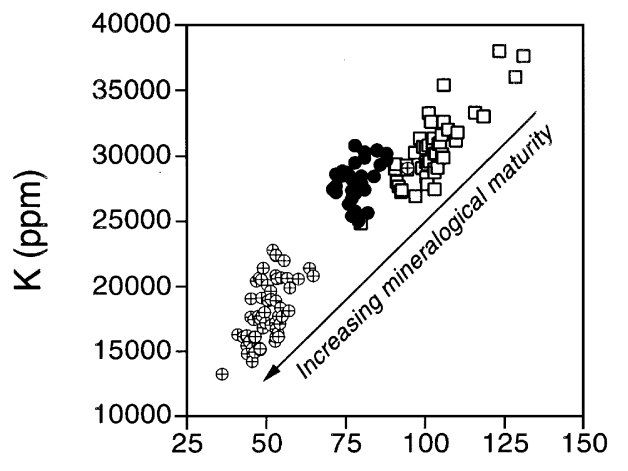

$\mathrm{Rb}(\mathrm{ppm})$

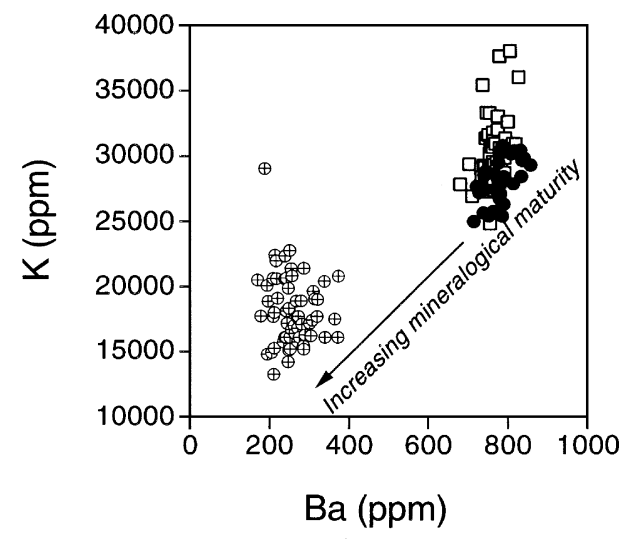

Great Bend eolian sand

Nebraska Sand Hills

Colorado eolian sand

Fig. 11. Plots of K vs. $\mathrm{Rb}$ and $\mathrm{K}$ vs. Ba for eolian sands from the Great Bend Sand Prairie, northeastern Colorado, and the Nebraska Sand Hills. Nebraska data from Muhs et al. (1997a); Colorado data from Muhs et al. (1996).

Geomorphic evidence also suggests that the mid-Holocene in the Great Plains may have been relatively dry. Recent studies in the Nebraska Sand Hills suggest that dunes were active there during the mid-Holocene, as well as before and after this period (Loope et al., 1995; Stokes and Swinehart, 1997). In Colorado, there are few eolian sands dated directly to the mid-Holocene, but these localities combined with soil-geomorphic relations indicate the possibility of mid-Holocene dune activity (Madole, 1995; Forman et al., 1995; Muhs et al., 1996). On the Southern High Plains of Texas, Holliday (1995b) reports that eolian sand deposition into draws was at a maximum during the early to mid-Holocene, widespread by $\sim 7500 \mathrm{yr} \mathrm{BP}$, but most important from 6500 to $4500 \mathrm{yr}$ BP. In addition, lunettes from this region also show evidence of mid-Holocene eolian activity (Holliday, 1997). Near Garden City, Kansas, loess deposits, assumed to be derived from the Arkansas River, appear to date from the mid-Holocene (Olson et al., 1997). Just west of the Great Bend Sand Prairie, a detailed and well-dated study of Holocene fluvial deposits in the Pawnee River valley shows that Holocene valley fills are devoid of any evidence of soil development between $\sim 7000$ and 5000 yr BP (Mandel, 1994). Mandel (1994) interprets this finding as the result of erosion and net transportation in small valleys, due to reduced vegetation cover during a warm mid-Holocene period. Collectively, these data suggest that the middle Holocene was a period of maximum dryness, and probably warmth, on the central Great Plains.

Although the stratigraphic and radiocarbon data of Arbogast (1996a) and Arbogast and Johnson (1998) indicate that much of the latest eolian activity in the Great Bend Sand Prairie occurred during the late Holocene, the underlying alluvium dates to the late Wisconsin, permit- ting the possibility of early or mid-Holocene eolian sand movement. Furthermore, dunes in the Great Bend Sand Prairie with relatively well developed $\mathrm{A} / \mathrm{Bt} / \mathrm{C}$ soil profiles (the Pratt series, a Psammentic Haplustalf) are not likely to be of late Holocene age, because such profiles probably take several thousands of years to develop, based on data from Colorado (Madole, 1995; Forman et al., 1995; Muhs et al., 1996). Therefore, we hypothesize that eolian sand movement out of the Arkansas River was at a maximum during the mid-Holocene, under drier conditions and northwesterly winds, due to a greater residence time of dry, Pacific-derived air over the region. A drier climate would also have led to greater sediment availability from the Arkansas River because of the likelihood of only intermittent summer flows and higher peak flows in spring, which would minimize valley-bottom vegetation cover (Muhs and Holliday, 1995). Given the spatial trends in $\mathrm{Ca}$ and $\mathrm{Sr}$ observed in this study, movement of sand from the valley bottom to the southeast must have been extensive. Subsequent late Holocene activity was apparently less profound in terms of sand volume, resulting only in local reactivation due to southwesterly winds; otherwise, the spatial trends of $\mathrm{Ca}$ and $\mathrm{Sr}$ abundances would not have been preserved. Nevertheless, in Kansas, as elsewhere on the Great Plains, there was widespread eolian sand movement in the late Holocene, clearly indicated by the stratigraphic and radiocarbon evidence presented by Arbogast (1996a).

\section{Conclusions}

The origin of eolian sand in the Great Bend Sand Prairie has been enigmatic, because no obvious source exists to the south of the dune field, yet modern 
sand-moving winds are from the south and orientations of dune forms reflect this wind direction. Mineralogy of eolian sands and the sand fraction of river sediments permits the possibility that eolian sand was derived from the Arkansas River, situated to the west and north of the dunes. This source implies a paleowind from the northwest during the main period of eolian sand emplacement. Carbonate minerals are hypothesized to decrease in abundance downwind in dune fields due to the high potential for these minerals to undergo abrasion and size reduction during transport. Using $\mathrm{Ca}$ and $\mathrm{Sr}$ concentrations as a proxy for carbonate mineral abundances, the Great Bend Sand Prairie shows a northwest-to-southeast decrease in these minerals. We interpret these trends to mean that most eolian sand in the Great Bend Sand Prairie was derived from the Arkansas River during a period of northwesterly winds. Northwesterly winds in this part of the Great Plains are associated with the presence of dry, Pacific-derived air. Eolian sand movement under such conditions would be enhanced because of drier paleoclimatic conditions and may have occurred during the mid-Holocene, based on pollen and sedimentologic data from elsewhere in the midcontinent. The present eolian landforms, with their orientations indicating southerly winds, are the result of intermittent late Holocene reworking under moister climate conditions.

\section{Acknowledgements}

This study was supported by the Global Change and Climate History Program of the U.S. Geological Survey. We thank Bill Johnson, Scott Crozier and Paul Rindfleisch for assistance in the field and Josh Been, Shannon Mahan, and Gary Skipp for assistance in the laboratory. Jim Swinehart, Nick Lancaster, Steve Wolfe, Randy Schaetzl and Vance Holliday reviewed an earlier version of this paper and made helpful comments for its improvement.

\section{References}

Ahlbrandt, T.S., Fryberger, S.G., 1980. Eolian deposits in the Nebraska Sand Hills. U.S. Geological Survey Professional Paper 1120-A, pp. $1-24$.

Ahlbrandt, T.S., Swinehart, J.B., Maroney, D.G., 1983. The dynamic Holocene dune fields of the Great Plains and Rocky Mountain basins, U.S.A. In: Brookfield, M.E., Ahlbrandt, T.S. (Eds.), Eolian Sediments and Processes. Elsevier, New York, pp. 379-406.

Aleinikoff, J.N., Muhs, D.R., Sauer, R.R., Fanning, C.M., 1999. Late Quaternary loess in northeastern Colorado, II: $\mathrm{Pb}$ isotopic evidence for the variability of loess sources. Geological Society of America Bulletin 111, 1876-1883.

Arbogast, A.F., 1996a. Stratigraphic evidence for late-Holocene eolian sand mobilization and soil formation in south-central Kansas. U.S.A. Journal of Arid Environments 34, 403-414.
Arbogast, A.F., 1996b. Late-Quaternary evolution of a lunette in the central Great Plains: Wilson Ridge, Kansas. Physical Geography 17, 354-370.

Arbogast, A.F., 1998. Late-Quaternary climate change and landscape evolution on the Great Bend Sand Prairie. Kansas Geological Survey Bulletin 242, 1-74.

Arbogast, A.F., Johnson, W.C., 1998. Late-Quaternary landscape response to environmental change in south-central Kansas. Annals of the Association of American Geographers 88, 125-146.

Baker, R.G., Gonzalez, L.A., Raymo, M., Bettis III, E.A., Reagan, M.K., Dorale, J.A., 1998. Comparison of multiple proxy records of Holocene environments in the midwestern United States. Geology 26, 1131-1134.

Blatt, H., Middleton, G., Murray, R., 1972. Origin of Sedimentary Rocks. Prentice-Hall, Englewood Cliffs, NJ.

Breed, C.S., Fryberger, S.G., Andrews, S., McCauley, C., Lennartz, F., Gebel, D., Horstman, K., 1979. Regional studies of sand seas using Landsat (ERTS) imagery. U.S. Geological Survey Professional Paper 1052K, pp. 305-397.

Bryson, R.A., 1966. Air masses, streamlines and the boreal forest. Geographical Bulletin 8, 228-269.

Cooke, R.U., Warren, A., 1973. Geomorphology in Deserts. University of California Press, Berkeley.

Dutta, P.K., Zhou, Z., dos Santos, P.R., 1993. A theoretical study of mineralogical maturation of eolian sand. Geological Society of America Special Paper 284, 203-209.

Forman, S.L., Oglesby, R., Markgraf, V., Stafford, T., 1995. Paleoclimatic significance of Late Quaternary eolian deposition on the Piedmont and High Plains. Central United States. Global and Planetary Change 11, 35-55.

Fredlund, G.G., 1995. Late Quaternary pollen record from Cheyenne Bottoms. Kansas. Quaternary Research 43, 67-79.

Fryberger, S.G., Dean, G., 1979. Dune forms and wind regime. In: McKee, E.D. (Ed.), A Study of Global Sand Seas, U.S. Geological, U.S. Government Printing Office, Washington, D.C. Survey Professional Paper, vol. 1052. pp. 137-169.

Holliday, V.T., 1995a. Late Quaternary stratigraphy of the Southern High Plains. In: Johnson, E. (Ed.), Ancient Peoples and Landscapes. Museum of Texas Tech University, Lubbock, TX, pp. 289-313.

Holliday, V.T., 1995b. Stratigraphy and paleoenvironments of late Quaternary valley fills on the Southern High Plains. Geological Society of America Memoir 186, 1-136.

Holliday, V.T., 1997. Origin and evolution of lunettes on the High Plains of Texas and New Mexico. Quaternary Research 47, 54-69.

Kuenen, Ph.H., 1960. Experimental abrasion 4: Eolian action. Journal of Geology 68, 427-449.

Lancaster, N., 1988. Development of linear dunes in the southwestern Kalahari, southern Africa. Journal of Arid Environments 14, 233-244.

Lancaster, N., Greeley, R., Christensen, P.R., 1987. Dunes of the Gran Desierto sand-sea. Sonora, Mexico. Earth Surface Processes and Landforms 12, 277-288.

Loope, D.B., Swinehart, J.B., Mason, J.P., 1995. Dune-dammed paleovalleys of the Nebraska Sand Hills: intrinsic versus climatic controls on the accumulation of lake and marsh sediments. Geological Society of America Bulletin 107, 396-406.

Madole, R.F., 1995. Spatial and temporal patterns of late Quaternary eolian deposition, eastern Colorado, U.S.A. Quaternary Science Reviews 14, 155-177.

Mandel, R.D., 1994. Holocene landscape evolution in the Pawnee River valley, southwestern Kansas. Kansas Geological Survey Bulletin 236, 1-117.

Marsland, P.S., Woodruff, J.G., 1937. A study of the effects of wind transportation on grains of several minerals. Journal of Sedimentary Petrology 7, 18-30.

McKee, E.D., 1983. Eolian sand bodies of the world. In: Brookfield, M.E., Ahlbrandt, T.S. (Eds.), Eolian Sediments and Processes, 
Developments in Sedimentology, Vol. 38. Elsevier, Amsterdam, pp. 1-25.

Muhs, D.R., Holliday, V.T., 1995. Evidence of active dune sand on the Great Plains in the 19th century from accounts of early explorers. Quaternary Research 43, 198-208.

Muhs, D.R., Bush, C.A., Cowherd, S.D., Mahan, S., 1995. Geomorphic and geochemical evidence for the source of sand in the Algodones dunes, Colorado Desert, southeastern California. In: Tchakerian, V.P. (Ed.), Desert Aeolian Processes. Chapman \& Hall, London, pp. $37-74$.

Muhs, D.R., Stafford Jr., T.W., Cowherd, S.D., Mahan, S.A., Kihl, R., Maat, P.B., Bush, C.A., Nehring, J., 1996. Origin of the late Quaternary dune fields of northeastern Colorado. Geomorphology 17, 129-149.

Muhs, D.R., Stafford Jr., T.W., Swinehart, J.B., Cowherd, S.D., Mahan, S.A., Bush, C.A., Madole, R.F., Maat, P.B., 1997a. Late Holocene eolian activity in the mineralogically mature Nebraska Sand Hills. Quaternary Research 48, 162-176.

Muhs, D.R., Stafford Jr., T.W., Been, J., Mahan, S.A., Burdett, J., Skipp, G., Rowland, Z.M., 1997b. Holocene eolian activity in the Minot dune field. North Dakota. Canadian Journal of Earth Sciences 34, 1442-1459.

Olson, C.G., Nettleton, W.D., Porter, D.A., Brasher, B.R., 1997. Middle Holocene aeolian activity on the High Plains of western Kansas. The Holocene 7, 255-261.

Pye, K., Tsoar, H., 1990. Aeolian Sand and Sand Dunes. Unwin Hyman, London.
Ross, J.A., Wong, M.K., Chyn, H.M., Wong, R.K.W., Kirshen, D.S., Wong, W.K., Collins, D.R., Ross, C.G., Brady, L.R., 1991. Geologic Map of Kansas. Kansas Geological Survey, Map Series 23, $1: 500,000$ scale.

Simonett, D.S., 1960. Development and grading of dunes in western Kansas. Annals of the Association of American Geographers 50, 216-241.

Smith, H.T.U., 1940. Geological studies in southwestern Kansas. Bulletin of the University of Kansas 41, 1-212.

Stokes, S., Swinehart, J.B., 1997. Middle and late Holocene dune reactivation in the Nebraska Sand Hills. The Holocene 7, 263-272.

Stramel, G.J., Lane, C.W., Hodson, W.G., 1958. Geology and groundwater hydrology of the Ingalls area, Kansas. University of Kansas Publications, State Geological Survey of Kansas Bulletin 132, $1-154$.

Swinehart, J.B., 1990. Wind-blown Deposits. In: Bleed, A., Flowerday, C. (Eds), An Atlas of the Sand Hills, Resource Atlas No. 5a. University of Nebraska-Lincoln, pp. 43-56.

Webb III, T., Bartlein, P.J., Harrison, S.P., Anderson, K.H., 1993. Vegetation, lake levels, and climate in eastern North America for the past 18,000 years. In: Wright Jr., H.E., Kutzbach, J.E., Webb III, T., Ruddiman, W.F., Street-Perrott, F.A., Bartlein, P.J. (Eds.), Global Climates Since the Last Glacial Maximum. University of Minnesota Press, Minneapolis, pp. 415-467.

Wells, S.G., McFadden, L.D., Schultz, J.D., 1990. Eolian landscape evolution and soil formation in the Chaco dune field, southern Colorado Plateau, New Mexico. Geomorphology 3, 517-546. 